\title{
THE SEDIMENTOLOGX STRATIGRAPHY AND TECTONIC CONTEXT OF THE SÃO FRANCISCO SUPERGROUP AT THE SOUTHWESTERN DOMAIN OF THE SÃO FRANCISCO CRATON-, BRAZIL
}

\author{
PAULO DE TARSO AMORIM CASTRO ${ }^{1}$ AND MARCEL AUGUSTE DARDENNE ${ }^{2}$
}

\begin{abstract}
Neoproterozoic metasedimentary rocks of the São Francisco Supergroup occur in the Southwest part of São Francisco Craton. Three informal lithostratigraphic units composed mainly by psephites, pelites and carbonates represent the São Francisco Supergroup. The last two units formed in storm influenced muddy shelf and platform/ramp systems, respectively. The psephitic unit crops out as isolated bodies nearby the external zone of the southernmost part of Brasilia Fold and Thrust Belt. Its origin is related to fan delta systems that developed eastward, in a foreland basin, as a result of erosion of metamorphic rocks of Brasilia Fold and Thrust Belt.
\end{abstract}

Keywords: Bambuí Group - São Francisco Craton - fan delta system - foreland basin

INTRODUCTION The extensive metasedimentary sequence that covers the southern and eastern portions of the São Francisco Craton was deposited during the Neoproterozoic as part of the São Francisco Supergroup (Pflug \& Renger 1973). The sequence was deformed during the Pan-African - Brasiliano orogeny, by the end of the Proterozoic times. Folds, thrusts and transcurrent faults verge to the interior of the Craton.

This paper reports some of the new results of researches on the sedimentology, stratigraphy and tectonics of the São Francisco Supergroup (Castro 1997, Castro \& Dardenne 1995,1997) addressing the depositional context in which the conglomerates and associated rocks were formed at the southwest border of the São Francisco Craton.

The studied region is located at the southwestern portion of the São Francisco Craton, just to the south of the parallel $20^{\circ} \mathrm{S}$, in the centereast of Brazil (Figs, la and b). This region corresponds to the Highlands of the São Francisco River basin.

The São Francisco Supergroup conglomerates are the main focus of the present study. Conglomerates are common in the surroundings of the watershed of the Rio Grande and Paranafba rivers. They are locally in the east flank of Serra da Pimenta, in the west flank of the Serra da Paciencia near Capitolio village, between the cities of Carmo do Rio Claro and Campo do Meio, in the place called Cristais and in the upper part of São Francisco river basin (Fig. Ic).

REGIONAL GEOLOGY Stratigraphy The São Francisco Supergroup is a neoproterozoic cover sequence, mainly composed of pelites and carbonatic sediments. It lies unconformably on granitemigmatite-greenstone basement, as well as on older sedimentary rocks from both the Espinhaço Supergroup and the Paranoá Group. The São Francisco Supergroup consists of two distinct sets: siliciclastic rocks, named Jequitai Formation in the western portion of the São Francisco Craton and, at the top, pelitic-carbonatic rocks of the Bambuí Group. According to Dardenne (1978), two conglomeratic units of the São Francisco Supergroup can be recognized in the western portion of the São Francisco Craton:

- the Jequitaí Formation, the basal unit, is essentially composed of paraconglomerates, exposed at the Jequitai village, close to the midwestern part of the adjacent Aracuai Fold Belt. Many authors consider it to be formed in one of the Neoproterozoic glacial events (Isolta et al. 1969, Hettich 1977).The Bambuí Group unconformably overlies the Jequitai Formation.

- the Sambura Formation, comprising the conglomerates of the southwestern portion of the São Francisco Craton, considered as the basal unit of the Bambuí Group.

Karfunkel \& Hoppe (1988) correlate the Sambura Formation to other conglomerates of the São Francisco Craton such as Jequitai and Bebedouro formations in the Chapada Diamantina region. They also suggest a glacial origin for all the siliciclastic rocks of the São Francisco Supergroup underlying the pelitic-carbonatic sequence of the Bambuí Group, which include the Ibia and Carandai formations, and the Macaubas Group, at the Brasilia, Alto Rio Grande e Araçuaí Fold Belts, respectively.
Tectonics According to Braun et al. (1990), the Bambuí Group, and specifically the Paraopeba Subgroup, originated in a passive margin basin that evolved from a rift basin. This basin was located close to the western portion of the São Francisco Craton. The Bambuí Group represents, therefore, cratonic cover deposits (Campos Neto 1984, Freitas Silva \& Dardenne 1992), The extensional event, was responsible for the deposition of the Brasilia Fold and Thrust Belt sediments as well as the cover sediments of the São Francisco Supergroup, (Schobbenhaus 1993, Fuck et al. 1993). It was followed by progressive contractional event, due to collision of the São Francisco, Amazonian and Rio de La Plata cratons during the Brasiliano Cycle.

On the other hand, Barbosa et al. (1970) and Valeriano (1992), based on the metamorphic and deformational history of the southern Brasilia Fold and Thrust Belt, suggest that the psephitic units of the São Francisco Supergroup (Samburá Formation) deposited in a foreland basin. This basin results from the fault stacking of the Araxá e Canastra metasedimentary rocks at the western boundary of the craton during the Brasiliano Cycle.

Deformation The region is divided in two distinct tectonic zones or domains that are related to the evolution of the Brasilia Fold Belt. The internal zone is characterized by nappes verging to SSE, such as Passos and Araxá nappe (Valeriano 1992, Simões \& Valeriano 1990). These nappes placed the Araxá metasediments on the external zone of the Brasilia Fold and Thrust Belt (Figs. Ib and c).

According to Pereira. et al. (1994), the external zone of the southern Brasilia Fold and Thrust Belt comprises thrust slices that verging to the craton and carrying the Ibia Formation and the Canastra Group over the cratonic sediments of the Bambuí Group. They are associated with transcurrent fault systems that crosscut the cratonic covers up to the cratonic area (Magalhães 1989).

THE SÃO FRANCISCO SUPERGROUP IN THE HIGH SÃO FRANCISCO RIVER The São Francisco Supergroup comprises four units, including a lower restricted siliciclastic unit to the north and three units associated to the Paraopeba Subgroup (Bambuí Group). This paper will focus on the top three units.

The São Francisco Supergroup sediments display a radial polarized metamorphic pattern varied from virtually no metamorphism in the central areas of the southern portions of the craton to greenschist facies at the Aracuaf e Brasilia fold belts borders (Dardenne 1978).

The Paraopeba Subgroup The Paraopeba Subgroup comprises three units that vary laterally from a rudaceous unit to the west to a carbonatic unit to the east (Figure 1 and 2). They are described in informal stratigraphic units as follows:

The carbonatic unit consists of black to gray limestone and dolomite, which are locally oolitic, calciruditic and, more rarely, stromatolitic. It also contains marls that locally show desiccation cracks. The unit crops out in the topographically lows of the Serra da Pimenta area. There, its map expression increases towards the north and the northeast. It consists of centimeter to decimeter thick calcilutites, less commonly decimeter thick oolitic limestone. 

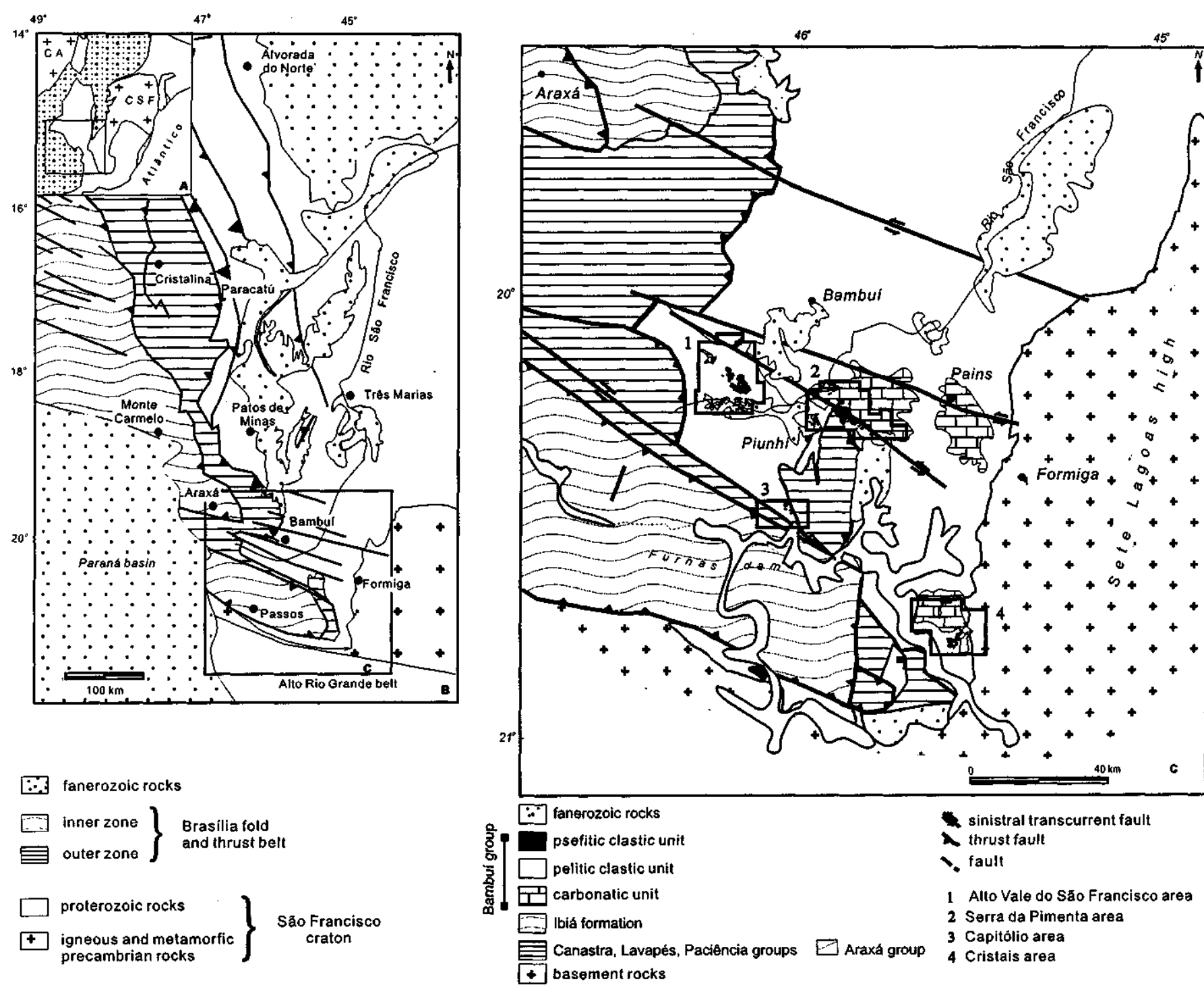

$\because$ fanerozoic rocks

$\left.\begin{array}{ll}\text { inner zone } \\ \hline \text { outer zone }\end{array}\right\} \begin{aligned} & \text { Brasilia fold } \\ & \text { and thrust belt }\end{aligned}$

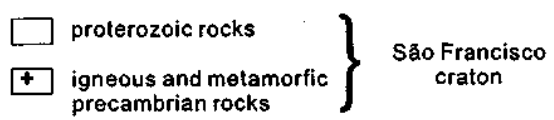

sinistral transcurrent fault thrust faul

Alto Vale do 55 o Francisco are

2 Serra da Pimenta area

(lio area

and the São Francisco Craton Figure J - Geologic context of the studied area, being situated in the bordering region between the Brasilia Fold and Thrust Belf and
in its southern portion (in b and c). Compiled after Schobbenhas (1993). Ca =Amazonian Craton; CSF $=$ Säo Francisco Craton.

Stromatolites are uncommon, predominating the dome-type, up to 20 $\mathrm{cm}$ wide, in beds less than $50 \mathrm{~cm}$ thick. In the Alto Rio São Francisco area the occurrence of this unit is more restrict and consists of dull gray laminated limestone with white calcite veins. Near the Sete Lagoas High, the unit overlies about $60 \mathrm{~m}$ of marls resting on basement rocks. Towards the top, the carbonate layers decrease in thickness due to the increase of amount of mud. Wavy calcareous layers prevail, some showing desiccation cracks or intraclasts. Near the area of Cristal, the calcareous rocks lie directly on the basement and consist of millimetric pelitic marl laminae.

The carbonatic unit is interpreted as been formed in a platform/ ramp system developed at the west flank of the Sete Lagoas High (Castro 1997, Nobre-Lopes 1995).

The pelitic clastic unit is essentially composed of pelites. It is widely distributed in the SW part of the São Francisco Craton. Centimetric thick lenses and beds of siltites are occasionally interbedded with pelites. Fine sandstone bodies are rare. Quartz, muscovite and kaolinite are the main constituents. The lower contact of the unit is concordant with the carbonatic unit and is well observed in all the studied regions. Rare lenses of oolitic and centimeter thick laminated limestone alternate with more silty pelites. Towards the east, near the Sete Lagoas High, this unit rests unconformably on basement rocks. From the Alto Rio São Francisco and the Serra da Pimenta areas to the east, arkosic sandstone up to $6 \mathrm{~m}$ in size are present. They show flat base and convex top, normal gradation. Truncated wave ripple cross laminations are common at the top of these bodies. This unit is interpreted to have been formed in a muddy shelf occasionally under

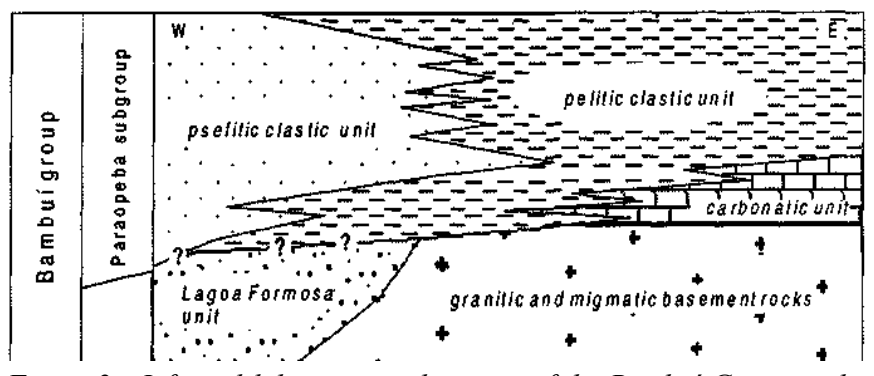

Figure 2 - Informal lithostratigraphic units of the Bambui Group at the Southwest part ofSão Francisco Craton.

the influence of storm conditions (Castro 1997). To the west, the pelitic clastic unit is laterally interbedded with the psephitic clastic unit.

Conglomerates, arkoses and pelites form the psephitic clastic unit. The conglomerates are matrix- or clast-supported, massive or normal grading. The conglomerate clast assemblage includes centimetric to decimetric sub-rounded quartz, quartzite, shale, limestone, acid metavolcanics, granite and basalt, whereas the matrix is composed of greenish (when fresh) silty sandstone. The matrix is sand to silt, and when unaltered, dull green to gray. The arkoses form tabular or lenticular, centimeter to decimeter thick bodies with normal grading. They are usually interbedded with pelites and less commonly with conglomerates. 
The pelites are thinly laminated with frequent detrital micas, and are interbedded with lenses and beds of fine to medium-grained sandstone and siltites. The pelites are composed of quartz, muscovite and kaolinite, gray when fresh and yellow when weathered.

This unit is about $200 \mathrm{~m}$ in thickness Its lower contact is well known at the Cristal area, where the psephitic clastic unit rests unconformably on the basement and both the carbonatic unit and the pelitic clastic unit.

At the Alto Vale do Rio São Francisco and the Serra da Pimenta, the lower contact of the psephitic clastic unit is not directly observed. But in regional cross-sections it conformably overlies the carbonatic unit. At the Serra da Pimenta, this unit rests unconformably on metavolcanic rocks of the Proterozoic Ribeirao Araras Group. In both regions, the psephitic clastic unit grades laterally to the pelitic clastic unit. In terms of the formal lithostratigraphy of Paraopeba Subgroup, the psephitic clastic unit encompasses the Sambura Formation. But differently from the earlier proposed position of this unit, it is not limited to the lowest part of the subgroup, but on the contrary, it is distributed in several levels along the Paraopeba Subgroup. (Fig.2)

The sedimentological data do not support a glacial influence in the depositional setting of the conglomerates of the psephitic clastic unit as admitted by other authors. Such glacial origin is admitted almost exclusively from lithostratigrafic correlation to the glaciogenic rocks of the Jequitai and Bebedouro formations (Karfunkel and Hoppe 1988, Tompkins and Gonzaga 1991)

Based on sedimentological logs and stratigraphic sections, the psephitic clastic unit deposited as a fan-delta. This depositional system developed due to the erosion of the nappes and thrust slices of the Araxá and Canastra groups. The nappes were thrusted onto the São Francisco Craton, in the southern portion of the Brasilia Fold and Thrust Belt. Such a tectonic context represents the earlier deposition stage in a foreland basin related to the São Francisco Craton, older than the Tres Marias Formation (Castro and Dardenne 1995, 1997, Guimaraes 1997).
There is a general trend to the fan-delta retrogradational system in some of the sedimentological logs. The dominance of more proximal psamitic facies gives rise to the predominance of more distal pelitic fades. Within this general retrogradational trend, coarsening upward and thickening upward sequences are related to the progradational events. The presence of progradational events internally to a retrogradational sequence can be associated to tectonic pulses in the most interior portions of the Brasilia Fold and Thrust Belt, where rocks of the Canastra and Araxá groups dominate. This fact would have resulted in an increase of the relief and in a more intensively retaken of the erosional processes.

Lithostratigraphic unit's distribution, with the psephitic sediments mainly located close to thrust slice fronts and the carbonates mainly located far from thrust fronts, also supports a foreland basin context. In such a context, the Sete Lagoas High would have acted as a forebulge region. This sedimentation polarity, with the coarsest facies (psephitic clastic unit) closer to the Brasilia Fold and Thrust Belt, represents the advance of the thrust fronts towards the east and the development of topographic high close to a depression, due to the overload caused by the accumulation of the thrust slices on the cratonic margin.

CONCLUSIONS The facies and facies association of the siliciclastic rocks of the São Francisco Supergroup at the SW portion of São Francisco Craton is formed in fan-delta systems developed eastward on the São Francisco Craton. Their source area was located to the west, on the Neoproterozoic highlands of the Brasilia Fold and Thrust Belt. The spatial distribution of the informal lithostratigraphic units of São Francisco Supergroup in the SW part of the São Francisco Craton is also a factor that supports this hypothesis. Deformation of these rocks and the progradational pulses recognized on fan-delta systems suggest an association between deformational events within the Brasilia Fold and Thrust Belt towards the SW part of São Francisco Craton and the generation of São Francisco Supergroup sediments in a foreland basin context.

Acknowledgements To two anonymous referees of RBG for suggestions to the original.

\section{References}

Barbosa 0., Braun O.P.G., Dyer R.C., Cunha C.A.B.M. 1970. Geologia da região do Triangulo Mineiro. Rio de Janeiro, DNPM/DFPM. 140p. (Boletim 136).

Braun O.P.G., Mello V., Delia Piazza H. 1990. Bacias proterozóicas brasileiras com perspectivas exploratórias para hidrocarbonetos In: Raja Gabaglia, G.P. \& Milani, E.J. (coords.) Origem e Evolução de Bacias Sedimentares. Rio de Janeiro, Petrobras. 115-132.

Campos Neto M.C. 1984. Litoestratigrafia, relações estratigráficas e evolução paleogeográfica dos grupos Canastra e Paranoá (regiao de Vazante-Lagamar, MG). Revista Brasileira de Geociências, 14:81-91.

Castro P.T.A. 1997. Os Conglomerados Associados ao Grupo Bambui na Porção Sudoeste do Cráton do São Francisco: Sedimentologia, Estratigrafia e Implicações Tectônicas. Inst. de Geociências, Universidade de Brasilia. Tese de Tectonicas. Inst.

Castro P.T.A. and Dardenne M.A. 1995. O conglomerado Sambura (Grupo Bambuí, Neoproterozoico) e rochas sedimentares associadas no flanco leste da Serra da Pimenta, SW de Minas Gerais: um sistema de fan-delta. Geonomos 3(2):35-41.

Castro P.T.A. and Dardenne M. A. 1997. Caracteristicas sedimentologicas e estratigraficas de los Conglomerados Samburá e rocas asociadas (Grupo Bambuí, Proterozoico Superior) en la region del Alto Rio São Francisco, SW de Minas Gerais, Brasil. In Congreso Latinoamericano de Sedimentologia, 1, Porlamar, Venezuela. Memorias... I, Porlamar. p.167-174.

Dardenne M.A. 1978. Síntese sobre a estratigrafia do Grupo no Brasil Central. In:: SBG, Congresso Brasileiro de Geologia, 30. Recife, 1978. Anais.... 2,:p.597-610.

Freitas Silva F.H. and Dardenne M.A. 1992. Quadro estratigráfico das Formações Paracatú e Vazante na regiao de Paracatu, MG. In: Simpósio de Geologia de Minas Gerais, 6 , Anais..., Ouro Preto, Revista da Escola de Minas, vol. 56, n. 1/2, p.91-93.

Fuck R.A., Jardim de Sa E.F., Pimentel M.M., Dardenne M.A., Pedrosa Scares A.C. 1993. As faixas de dobramentos marginais do Craton do São Francisco. In J.M.L.Dominguez \& A. Misi (eds.) O Craton do São Francisco. Salvador, Sociedade Brasileira de Geologia, 161-185.

Guimaraes E.M. 1997. Estudos de proveniencia e diagenese com enfase na caracterização dos filossilicatos dos grupos Paranoá e Bambuí, na região de Bezerra - Cabeceiras $(G O)$. Inst. de Geociências, Universidade de Brasilia. Tese de doutoramento. $269 \mathrm{p}$.

Hettich M. 1977. A glatiação proterozóica no centro-norte de Minas Gerais. Revista Brasileira de Geociências, 7(2):87-101.

Isotta C.A.L., Rocha-Campos A.C., Yoshida, R. 1969. Striated pavement of the upper Precambrian glaciation in Brazil. Nature 222(5192):466-468.

Karfunkel J.and Hoppe, A. 1988. Late Proterozoic glaciation in Central-Eastern Brazil synthesis and model. Palaeogeography, Palaeoclimatology, Palaeoecology 65:1-21.

Magalhaes P.M. 1989. Andlise estrutural qualitativa das rochas do Grupo Bambuí, na porção sudoeste da Bacia do São Francisco. Escola de Minas, Universidade Federal de Ouro Preto. Dissertação de mestrado. 100p.

Nobre - Lopes J. 1995. Faciologia e genese dos carbonatos do Grupo Bambuína regiao de Areas, Estado de Minas Gerais. Inst. de Geociências, Universidade de São Paulo. Disserta9 9 o de mestrado.

Pereira L.F., Dardenne M.A., Rosiere C.A., Pedrosa-Soares A.C. 1994. Evolucão geológica dos grupos Canastra e Ibia na região entre Coromandel e Guarda-Mor, MG. Geonomos, 2N):22-32.

Pflug R. and Renger F. 1973. Estratigrafia e evolução geologica da margem SE do Cráton do São Francisco. In: SBG, Congresso Brasileiro de Geologia, 27, Aracaju, 1973. Anais... 2, p.5-19.

Schobbenhaus C. 1993. O Proterozóico Médio no Brasil com enfase a região centro-leste: uma revisão. Universidade de Freiburg. Tese de doutoramento $166 \mathrm{p}$.

Simoes L.S.A.and Valeriano C.M. 1990. Porção meridional da Faixa de Dobramentos Brasilia: estagio atual do conhecimento e problemas de correlação tectonoestratigráfica. In: SBG, Congresso Brasileiro de Geologia, 36, Natal, 1990. Anais. 6. p.2564-2575.

Tompkins L.A.and Gonzaga G.M. 1991. Geologia do diamante. In: Schobenhaus, C.; Queiroz, E.T.; Coelho, C.E.S. coords. 1991. Principais depositos minerals do Bra-

Queiroz, E.T.; Coelho, C.E.S. coords. 1991. Princip

sil, vol. 4-A, p.53-113. DNPM/CPRM. Brasilia.
Valeriano C.M. 1992. Evolução tectônica da extremidade meridional da Faixa Brasilia, regiao da Represa de Furnas, sudoeste de Minas Gerais. Inst. de Geociências, Universidade de São Paulo. Tese de doutoramento. 192p.

Contribution IGC-106

Received March 2,2000

Accepted for publication April 20,2000 